\title{
HYBRID WAR: REAL CASUALTIES IN UKRAINE
}

\begin{abstract}
The Russo-Ukrainian war that broke out in 2014 in the wake of Russia's annexation of Crimea continues to be all too rarely noticed in the West. Observers comment widely on the novel 'hybrid' character of warfare as developed and trialed by the Kremlin worldwide during the recent years, but pay scant attention to the Russian 'training ground' in eastern Ukraine. The article probes into the realities of the ongoing RussoUkrainian war, alongside the ideological underpinnings of the Kremlin's intervention and Ukraine's response to this attack. It appears that the Russian government adopted ethnolinguistic nationalism, typical of Central Europe, namely, that all Russian-speakers constitute the Russian nation, especially if their communities compactly inhabit areas directly bordering on the Russian Federation.
\end{abstract}

Key words: ethnolinguistic nationalism; hybrid war; RussoUkrainian war; Russia; Ukraine

\section{WOJNA HYBRYDOWA: PRAWDZIWE OFIARY WOJNY ROSYJSKO-UKRAIŃSKIEJ}

\section{Streszczenie}

Wojna rosyjsko-ukraińska, która wybuchła w 2014 r. w następstwie aneksji Krymu przez Rosje, jest nadal zbyt rzadko zauważana na Zachodzie. Obserwatorzy szeroko komentuja "hybrydowy" charakter działań wojennych, wypracowywanych i wypróbowywanych przez Kreml po całym świecie w ciągu
TOMASZ KAMUSELLA University of St Andrews, St Andrews E-mail: tomek672@gmail.com

CITATION: Kamusella, T. (2018). Hybrid War: Real Casualties in Ukraine. Sprawy Narodowościowe. Seria nowa, 2018(50). https://doi.org/10.11649/sn.1637

This work was supported by the author's own resources. No competing interests have been declared.

\section{......}

1 I thank Leonid Zashkilnyak (Ivan Franko National University of Lviv), Iaroslav Hrytsak (Ukrainian Catholic University, Lviv), Catherine Gibson (European University Institute, Florence), Kurt Bassuener (University of St Andrews), alongside Jacek Serwański and Anna Jawor at Sprawy Narodowościowe / Nationalities Affairs for their helpful comments and suggestions.

This is an Open Access article distributed under the terms of the Creative Commons Attribution 3.0 PL License (creativecommons.org/licenses/by/3.0/pl/), which permits redistribution, commercial and non-commercial, provided that the article is properly cited. (C) The Author(s) 2018.

Publisher: Institute of Slavic Studies, Polish Academy of Sciences 
ostatnich lat, lecz nie zwracają uwagi na rosyjski „poligon doświadczalny" we wschodniej Ukrainie. Artykuł analizuje realia toczącej się tam wojny rosyjsko-ukraińskiej, jak i ideologiczne założenia interwencji militarnej Kremla oraz reakcję Ukrainy na tenże atak ze strony Rosji. Wydaje się, że rosyjski rząd przyjął jako uzasadnienie etnolingwistyczny nacjonalizm (typowy dla Europy Środkowej), a mianowicie, że wszystkie osoby rosyjskojęzyczne to członkowie narodu rosyjskiego, zwłaszcza jeśli ich społeczności zamieszkują tereny bezpośrednio graniczące z obszarem Federacji Rosyjskiej.

Słowa kluczowe: nacjonalizm etnicznojęzykowy; Rosja; Ukraina; wojna hybrydowa; wojna rosyjsko-ukraińska

\section{RUSSIA'S POST-SOVIET WARS}

\section{T} he undeclared Russian onslaught on Ukraine commenced in late 2013. The Euromaidan Revolution (also, and in my view more appropriately, known as the Revolution of Dignity) held in Kyiv and some other Ukrainian cities in the dead of the 2013/14 winter showed the determination of the Ukrainians to join the Euro-Atlantic structures (Chupryna, 2014). The government of Mr Viktor Yanukovych-discredited by making Ukraine tightly allied with Russia (some would say that even into 'a Russian colony') against the will of the majority of the Ukrainians hoping for their country's accession to the European Union (Dempsey, 2014; Moser, 2013; Velychenko, 2013)—ordered the use of live ammunition and snipers against the peaceful protesters. Yanukovych and his closest associates then fled (with whatever they could grab of their amassed ill-gotten fortunes) to their pay and taskmaster in Moscow. The undeclared Russian onslaught on Ukraine swiftly followed. It is the largest and most tragic international conflict between post-Soviet states in Europe. The 1992 Russo-Moldovan war in eastern Moldova (or Transnistria) left around 1,000 dead in its wake (Dal Santo, 2015). Sixteen years later, the casualties of the 2008 Russo-Georgian war in the nominally Georgian autonomous republics of Abkhazia and South Ossetia amounted to over 600 ("Russo-Georgian war", 2017). ${ }^{2}$ In the ongoing Russo-Ukrainian war 11,000 to 15,000 people have been killed by mid-2017 (J. Harding, 2016; Petrov, 2017b) and 1.6 million have left the warzone as internal or international refugees ("Ukraine: Global focus", 2017). . To this number, 50,000 refugees from Russian-occupied Crimea must be added (Berezovets, 2015). The scale of the human losses and tragedy in this conflict quickly approaches that of the intra-Soviet and subsequently post-Soviet Armenian-Azeri war (1988-1994), which killed over 20,000 people (Zürcher, 2007, pp. 179-180), sending a wave of 1.2 million refugees and IDPs away from their homes (Frelick, 1994; Rettman, 2017). Fortunately, for the time being, the casualties caused by the Russian attack on Ukraine do not approach the genocidalscale bloodbath of the two Russo-Chechen wars (1994-1996, 1999-2009) with the staggering death toll of $200,000-300,000$ out of the total population of over $800,000 .^{4}$

2 Moscow prefers the unsubstantiated number of 2,000 casualties, mostly non-Georgians purportedly killed by Georgian forces (Cheterian, 2009, p. 160).

3 Some would add to the aforementioned estimate 400,000 refugees who found shelter in Russia (cf Semenovich, 2016).

4 This is a high estimate of the casualties, including Russian soldiers. Due to political reasons, there is not a single reliable register of those who lost their lives during the two recent Russo-Chechen wars. Obviously, Moscow and the pro-Kremlin government of today's Chechnia prefer lower estimates of casualties, hovering around 120,000 (Riazantsev, 2005).

Chechen and western sources quote numbers that are substantially higher, even twice and three times the Russian official estimate ("Chechen official", 2005; "Over 200,000", 2004; Strade, 2005). 
In contrast to the current Russo-Ukrainian war, the Armenian-Azeri conflict was largely a Soviet civil war, just as the Russo-Chechen conflicts were Russian civil wars. They were all fought (with the lone exception of the still somewhat 'Soviet' Transnistrian conflict) within the borders of a single polity. Hence, the level of violence the Vladimir Putin administration is now ready to unleash on a sovereign nation-state bordering Russia in the case of the ongoing intervention in eastern Ukraine is unprecedented. The number of human losses-own and inflicted-seems to be fast becoming a non-issue. In Russia's wars against Moldova and Georgia, the Kremlin seemed to take care to limit the number of casualties. However, the Russian administration seems to have gradually developed an immunity to an increasing death toll with each conflict of this kind. This acceptance of casualties still does not compare with that tolerated in the Soviet Union. The Kremlin decided to pull out of Afghanistan only after the Soviet decade-long intervention had left between 600,000 and 2 million dead in its wake (Katzman, 2003, p. 219; Khalidi, 1991, p. 101; Lacina \& Gleditsch, 2005, p. 154).

Significantly, all the conflicts fought by post-Soviet Russia outside its own territory took place in Europe. This direction seems to indicate Moscow's geopolitical priorities, among others, entailing a certain resignation from Siberia and the Far East, progressively drawn into China's economic (and political?) orbit ("Unlikely partners", 2017, p. 52). After 1991, the Kremlin exclusively attacked other post-Soviet states, viewed from the perspective of Boris Yeltsin's doctrine of 'near abroad' (blizhnee zarubezh'e) as parts of Russia's exclusive sphere of influence. Not a single post-Soviet state was attacked by Russia in post-Soviet Asia. These polities typically are more authoritarian than Russia itself, and mostly do the Kremlin's bidding, with the qualified exceptions of Turkmenistan and Uzbekistan. Uniquely, the former polity is one of the most repressive in the world, on a par with North Korea or Eritrea. Between 1991 and 2006 Ashgabat expelled two-thirds of its Russian (Russophone) population, or over 200,000. At present about 100,000 Russians (or Orthodox Russian-speakers) remain in Turkmenistan, though officially Ashgabat acknowledges only 50-odd individuals as Russians who still reside in the country ("Russians 'flee'", 2003)..$^{5}$ The official policy of Turkmenization was declared to have been successfully completed in the first decade of the $21^{\text {st }}$ century. Nowadays only Turkmens live in Turkmenistan. With its rich oil resources, one would think that this state should be the foremost target of the Kremlin's ire, especially after the drastic ethnic cleansing of ethnic Russians. However, fortunately for Ashgabat, the country is isolated from Russia by Kazakhstan and the Caspian Sea. After 2009, most of Turkmen gas flows now to China rather than Russia. Ashgabat appears to have left the Russian sphere of influence, and Turkmenistan effectively became a Chinese satellite. Somehow, the Kremlin has acquiesced to this seismic shift in the Asian geopolitics (Babaeva, 2016; Sorbello, 2017).

The 'oil-less' Ukraine appears more important to the Kremlin's strategists than Turkmenistan. Kyiv - the ancient capital of medieval Rus'-is now the capital of Ukraine, though the Russian national master narrative claims specious historical and political continuity between Rus' and Russia. The medieval polity is typically dubbed 'early Russia' (drevniaia Rossiia) in Russian school textbooks and even in scholarly works (cf Solov'ev,

\section{......}

Furthermore' at the beginning of the first Russo-Chechen war, in 1991-1992, Ingushetia was separated from the Chechen-Ingush Autonomous Soviet Socialist Republic as a separate autonomous republic, which complicates any follow-up statistics. In 1989 the population of the Chechen-Ingush ASSR was comprised of 734,000 Chechens, 294,000 Russians (Russophones), 164,000 Ingushes and 14,000 Armenians ("Vsesoiuznaia perepis'", n.d.).

5 Obviously, some Russians (Russophones) left Turkmenistan out of their own volition, hoping for a life in a democratic country. 
1997). In the eyes of a Russian imperialist or nationalist, Ukraine is an inalienable part of the East Slavic world, seen as Russia's cultural and political zone of influence. In this scheme, the Ukrainians and Belarusians are perceived to be the 'younger brethren' of the Russians. It is the Russians who lead. They know better what is good for the 'younger siblings,' meaning all the modern post-Rus' polities.

In the Kremlin's view the European (that is, Slavic) part of Russia, together with Ukraine (except for Western Ukraine, or Galicia, which the Moscow considers as 'lost' for the Russian cause, due to the region's overlong exposure to western ideas in the Habsburg Monarchy) and Belarus constitute the indivisible ethnopolitical core of Russia. This ideology of Great Russianness, with disregard for any ethnic, linguistic, cultural, religious, historic, or political distinctiveness of the Belarusians and Ukrainians originated in the Russian Empire and continued under a variety of guises in the Soviet Union. For instance, the Soviet Union had three seats in the United Nations, one for the Soviet Union itself (or in reality, for Russia), while the other two for Belarus and Ukraine. Yet, this arrangement was not to acknowledge the separateness of the two latter republics vis-à-vis Russia, but rather to emphasize the joint sovereignty of the Great Russians and their importance on the international scene, in comparison to the 'imperialist Americans' with just a single seat in the United Nations (Bailey \& Daws, 1995, p. 15).

A legacy of this ideology persists in today's Ukraine, weakening somewhat the country's ability to defend itself against the ongoing Russian military aggression. For instance, in 2015, after two years of war, a sociological poll found out that 54 per cent of Ukrainians saw Russia as a country that was the closest to Ukraine from among any other foreign (including post-Soviet) states. Even more, because over 66 per cent of Ukrainians declared that they felt a strong or very strong affinity with Russian language and culture (Zashkil'niak, 2016). It means that as many as two-thirds of Ukrainians are inclined to get opinions and news from Russia's mass media, opening themselves willingly or inadvertently to the Kremlin's anti-Ukrainian propaganda. However, contrary to what the Putin administration may like to think, it does not mean the Ukrainians would acquiesce to a Russian conquest or partition of their state. As a matter of fact, the popular support for the independence of Ukraine as a state remains robust. In the wake of the Russian annexation of Crimea it rapidly spiked from 75 to over 90 per cent (I. Hrytsak, personal communication, July 16, 2017; Soldak, 2014) (a similar phenomenon was observed in the rise of the Ukrainians' support for their country's membership in NATO; McLaughlin, 2017).

The hard facts of the war that Russia currently wages against Ukraine slowly attenuate the aforementioned Russophilia, which is still widespread among the Ukrainians. Rather, it should actually be interpreted as nostalgia for the Soviet Union or a postcolonial longing for the once largest land empire in the world-an empire in which Ukrainians also had a stake, as civil servants, soldiers, entrepreneurs, railwaymen, or settlers (Loza, 2015, pp. 198-199). ${ }^{6}$ The situation is similar to a generalized and rather vague pro-British sentiment among the Irish or Scots whose ancestors (at least some of them) used to profit quite substantially from participating in the expansion and maintenance of the worldwide British Empire. Despite speaking and writing in English, participating in global Anglophone culture and literature-which is this empire's lasting legacy-no Irish would agree to

\section{-...}

6 The participation of ethnic Ukrainians ('Cossacks') in this settlement of the Russian Empire's new territories along the north Black Sea littoral and in the Caucasus is lauded as an extension of the 'Ukrainian ethnographic territory' (cf Loza, 2015, pp. 196-197, 234-235), but it is rarely remarked that this process entailed the simultaneous expulsion and even extermination of the Turkicphone and Circassian-speaking Muslim populations (Donaldson, 1877; McCarthy, 1995; Richmond, 2013; TSutsiev, 2007, pp. 20-23, 31-35, 38, 69-70). 
Ireland's loss of independence to Britain, and likewise hardly any Scot would consent to a Scotland with no devolved status (that is, the country's wide-ranging autonomy in present-day Britain).

Ukrainian liberal historiography has long proposed that the main difference between the Ukrainians and Russians is not delineated by culture and language, as typical of central Europe. As a matter of fact, both nations linguistically and culturally are closely related, and have mostly refrained from politicizing this type of difference as the basis of separateness. These two nations differ most substantially in the realm of civic values, and political attitudes and traditions; the Russian tradition stemming from Muscovian autocracy, while its Ukrainian counterpart from Poland-Lithuania's noble democracy and Austria-Hungary's parliamentarianism. The fundamental difference between the Ukraine and Russia rests in how both nations approach relations between state and society, and how Ukrainians and Russians (or people identifying as Ukrainians and Russians, irrespective of their linguistic, ethnic or religious background) believe these relations should be organized. In their thinking on this matter, the former prefer democracy and the rule of law as practiced in the west (I. Hrytsak, personal communication, July 16, 2017; Rudnytsky, 1987). On the other hand, the latter extoll the civilizational uniqueness of Russia's political system, alongside some 'historical mission' (cf Hille \& Seddon, 2016; Kalb, 2008; Poltoratzky, 1967) that this country is supposed to fulfill for the sake of the entire world. In practical terms, the Russian case sizzles down to an authoritarian empire ('large state') led by a single ruler ('strongman') (I. Hrytsak, personal communication, July 16, 2017).

The partial ban on Russian software, online social media platforms and traditional mass media (that used to give the Kremlin's intelligence services a backdoor access to Ukraine's vital state systems and the possibility to shape the country's public opinion) introduced in 2017 (Bershidsky, 2017; Luhn, 2017; "Ukraine bans its top social networks", 2017) should have been introduced already four years ago. Time is of the essence. Each additional day that the Kremlin has the opportunity to expose the Ukrainians to Russian propaganda may tip the precarious balance of attitudes held by the public opinion in a direction that might facilitate Russian victory. To many a Ukrainian, it is still appalling that the choice of Russian-language titles is now rather limited in bookshops across Ukraine, and that such Russian publications are actually banished to the section with books in foreign languages. Furthermore, Russian-language films for broadcasting in Ukraine must now be supplied with Ukrainian subtitles (this policy began some 15 years ago, but now is strenuously enforced). However, in central Europe, where in line with the strictures of ethnolinguistic nationalism, language is so strongly equated with nation and statehood, it cannot be the other way around. The post-Soviet states of Estonia, Latvia and Lithuania also follow this paradigm. The need to prioritize language politics is especially true of Ukraine's situation now, when Moscow chooses to emphasize the Russian language as the main indicator of where Russia's 'true borders' should extend beyond today's Russian Federation. At present the Kremlin shares central Europe's normative political belief that a proper nation-state must enjoy its own separate language. This is the Ukrainian language in Ukraine. Hence, if more printed and online material would have continued to be available in Russian rather than in Ukrainian, Kyiv would have made itself vulnerable to Moscow's propaganda, which claims that the majority of Ukraine's population are Russian-speakers, meaning 'Russians' from the Kremlin's perspective. ${ }^{7}$

7 Obviously, the push for making Ukrainian the sole accepted and legal medium of business, technology and scholarship in today's Ukraine comes at a cost, because Russian has traditionally dominated in these 
This danger is keenly perceived by numerous Ukrainian politicians and commentators. Interestingly, after the Euromaidan Revolution, some Russian-speaking Ukrainians of a liberal persuasion proposed to redefine the Russian language as employed in Ukraine's public sphere (I. Hrytsak, personal communication, July 16, 2017). They argued that Russian, like English, became de-ethnicized due to the centuries-long employment across the sprawling expanses of the multicultural Russian Empire, which in its last period morphed into the Soviet Union. For that matter such a phenomenon of de-ethnicization is commonplace in the case of any post-imperial languages. For instance, an English-speaker cannot be automatically identified as an Englishwoman, she may also be a Canadian, American, Jamaican, Pakistani or Zimbabwean. Likewise, a Portuguese-speaker may be an Angolan or Brazilian, not only a Portuguese. From this point of view, speaking Russian cannot be interpreted as the person's declaration of Russian ethnic or civic identity. A Russian-speaker may also be a Ukrainian, Israeli, Kazakh, or Latvian. That is why, as in a computer's settings one can choose between US, UK or New Zealand English, one should also enjoy a similar opportunity to choose between Ukrainian, Muscovian (Rossiiskil), Kazkh(stani) or Latvian Russian.

To this end, a comprehensive dictionary and grammar of Ukrainian Russian ${ }^{8}$ could be compiled with an emphasis on specific vocabulary and phrases that reflect Ukraine's sociopolitical and cultural character. Unfortunately, as to my knowledge, no dictionary (or grammar) of Ukrainian Russian has been attempted yet, let alone published. An Austrian attending elementary school in Vienna or Graz is required to consult an Austrian dictionary of the German language recommended by the Ministry of Education, not a dictionary of this language published in Germany or Switzerland. I keep fingers crossed that in not too distant a future Russian-speaking Ukrainians may have the opportunity to avail themselves of a state-approved dictionary of Ukrainian Russian, and software companies may reply to this demand by including Ukrainian Russian as an option in computer language settings. ${ }^{9}$

\section{A NEW RUSSIAN WORLD}

The Kremlin is silent on the geopolitical expansion of China in post-Soviet central Asia, careful not to anger Beijing. The American diplomat and political scientist Zbigniew Brzeziński predicted that after the breakup of the Soviet Union Russia faces the existential

\section{- • - •}

spheres. It was the war effort and its geopolitical context that forced this change on Ukraine. Should this situation persist, perhaps, it means than in the span of a decade or so, English may take over Russian as Ukraine's preferred international lingua franca.

8 By saying 'Ukrainian Russian' I do not mean Surzhyk, or a highly changeable mixed variety of Ukrainian and Russian (or at times, Polish) that sprang up when Russification enforced in Soviet Ukraine caused numerous Ukrainophones to aspire to speak in Russian as a marker of their social and economic advancement. Often this aspiration was not propped up with more than rudimentary or elementary education in Russian. As a result, numerous lexical and syntactic similarities between both languages led many socially mobile Ukrainian-speakers (alongside ethnically Russian civil servants in Ukraine) to believe-wrongly-that there is no substantial gap between standard Ukrainian and standard Russian. Of course, if the stigma of a 'low variety' is removed from Surzhyk (which is at present unlikely), it could be standardized into a language in its own right. But such a development could play in the Kremlin's hands, because on this linguistic basis Moscow could propose that the eastern half of Ukraine is inhabited by a 'Surzhyk nation' that is different from the Ukrainian nation. A pronouncement of this type could justify Russia's efforts to separate (or even annex) eastern Ukraine's industrial regions from the rest of the country (cf Hentschel, Taranenko, \& Zaprudski, 2014). (I thank Catherine Gibson for drawing my attention to this aspect.)

9 Obviously, another option would be to rename the Russian language in Ukraine (for instance, as 'Rusan' or 'Rosan' from Rus', or the 'Kyivan language' from the capital of Rus'), and fashion it into a language in its own right, separate from both Russian and Ukrainian. This route was followed in the post-Yugoslav countries, where the former Serbo-Croatian was replaced with Bosnian, Croatian, Montenegrin and Serbian. But an option of this kind does not seem to be on the cards in Ukraine. 
choice of becoming a democratic country allied with the West, or will succumb to China's overwhelming economic, political, and cultural influence (Brzezinski, 2017). ${ }^{10}$ Neither of these options appeals to Mr Putin. His administration's sights, in line with the $18^{\text {th }}$-century Petrine tradition, are set squarely on the west. The goal is not to join the Euro-Atlantic structures, but rather that Russia may retain its status as global power, simultaneously doubling as a civilization in its own right. A civilization that would use the west's technological and other achievements for Russia's own political and cultural projects (for instance, 'managed democracy') and try to make as much of Europe as possible part of Moscow's sphere of influence (cf Grier, 2003). But at present with insufficient economic resources to hand for carrying out such a project on its own (TSygankov, 2007, p. 215), Moscow hopes to veer between the West and China, so that both would do its bidding. The currently worsening relations between the Unites States and China stand in contrast to the Kremlin's happy rapport with Beijing. American President Donald Trump's erratic governance is not helping to repair the US's ties with China and seems to be pushing both states on a collision course (Phillips, 2017). Meanwhile, Mr Trump's unreasonable praises of Mr Putin and his Russia diminishes Europe's and China's faith in Washington's stability and predictability. ${ }^{11}$ As a result, the Kremlin has been left to do as it pleases in the European 'near abroad,' far from both China and the increasingly isolationist United States.

To the outside observer, the Kremlin's ambition seems to aim at transforming Russia into a homogenous ethnolinguistic nation-state, as is usual in central Europe. Many commentators point out that over 80 per cent of Russia's population is ethnically Russian. Furthermore, in 2002 the Russian Duma (Parliament) passed a law that requires all languages indigenous to the Russian territory to be written exclusively in Cyrillic, which is popularly termed the 'Russian alphabet.' But to a degree, Mr Putin, for the sake of domestic opinion, blurs the distinction between 'Russian-in-ethnic terms' (Russkii) and 'Russian -in-civic-terms' (Rossiiskii). The latter term refers to the entire Russian Federation or even to all the post-Soviet space, understood as the historical and territorial legacy of the Russian Empire (perhaps, with a qualified exception of the Baltic republics of Estonia, Latvia and Lithuania, because they had functioned as independent nation-states in the interwar period). On the other hand, the concept Russkii may be interpreted narrowly as referring to Russians, namely, all Russian-speakers, or even exclusively to Russophone Orthodox Christians. The broader interpretation encompasses all the East Slavophone Orthodox faithful, or the Russians, together with the Belarusians and Ukrainians. In the typically imperial manner, Mr Putin plays with all these interpretations, deploying that whichever may suit the Kremlin's needs at a given moment.

About the time when the process of Turkmenization was completed in Turkmenistan, Moscow adopted a new policy of the 'Russian world' (Russkii mir) in 2007. It entails that all the territories adjacent to Russia and compactly inhabited by Russian-speakers are 'naturally' part of this world; potentially 'unredeemed parts' of the 'true' Russian nation-state (Moore, 2002), in the late $19^{\text {th }}$-century tradition of Italian irredentism ("About Ruskiyi Mir Foundation", 2017; Zakem \& Saunders, 2016). This national polity comes in the overcoat of the renewed Russian Empire, now translated into a seemingly economic form of the Eurasian Economic Union (EAEU) ("Sergei Naryshkin", 2012). Armenia and Kyrgyzstan are 'ornamental' additions to this Union, while its core is the 'internal Russian world'

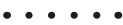

10 I thank Kurt Bassuener for drawing my attention to this scenario.

11 The 2017 tension between the US and North Korea seems also to be forcing a wedge between Beijing and Washington (Kirby, 2017). 
comprising Russia, Belarus and (especially northern) Kazakhstan. ${ }^{12}$ From the perspective of Russian history, this new policy seems to be a revival of the project of the gathering of the 'Russian' (Rus') lands, originally commenced in the early $16^{\text {th }}$-century Muscovy. It was coupled with the parallel but the never officially declared process of the 'gathering the lands of the Golden Horde' (as termed by the German historian of multicultural Russia, Andreas Kappeler); hence, the Kremlin's present-day insistence that the EAEU includes ethnically non-Russian states in the Caucasus and central Asia.

From the Kremlin's perspective, the pivotal piece that is still missing from this Russian world-under-construction is Ukraine, alongside Moldova and 'Russian Europe' (russkaia Evropa) (cf Lishka, 2008; "Russkaia Evropa", 2017; "Zhit' v 'Russkol Evrope'", 2017) or 'our Europe' (nasha Evropa) (cf Gil'ferding, 2010; honigkuchen, 2016; Kirsis, 2001; Lakshin, 2016; "Nasha Evropa", 2016; Zima, 2018). The last concept-largely unofficial, though it crops up in Russian journalese and titles of Russian-language guidebooks-typically encompasses the post-Soviet polities of Estonia, Latvia, and Lithuania, which now are members of the EU and NATO. In addition, the danger is for Helsinki that Moscow may also count Finland in this vague and malleable concept of the Russian world, should the country dare to join NATO. However, in the current pattern of Russian thinking on geopolitics, the main element of the Russkii mir jigsaw that must be expeditiously dealt with is Ukraine. Only after having secured this country, would the Putin administration feel comfortable in its endeavors to expand hard Russian influence farther across the rest of the potential zone of the Russian world, including actual annexations of territory. Ideally, the frontiers of 'true Russia' should overlap with the full extent of the Russian world.

The Russian decision to attack Ukraine and seize Crimea came at a cost. The main foundation of the postwar political architecture of peace and stability in Europe and the post-Soviet area was cast aside, namely the Helsinki Accords of 1975 ("Helsinki Final Act, 1975", 2017). The Kremlin violated most of the Accords' ten principles, including the crucial Articles 3 and 4 that declare the post-1945 frontiers to be inviolable and guarantee the territorial integrity of the extant polities. In the future, this breach of the established political order will be seen as the end of the postcommunist transition period, and the harbinger of a new, as yet nameless, era. The Russian war waged against Ukraine, with no sufficiently vocal protests (let alone a political or military action) on the part of the United States or Britain, showed that the 1994 Budapest Memorandum on Security Assurances was worth less than the paper to which it was committed.

In accordance with this document, Belarus, Kazakhstan, and Ukraine gave up their post-Soviet stockpiles of nuclear weapons to Russia. This was done in exchange for the assurance of sovereignty and territorial integrity of the three aforementioned states, as jointly guaranteed by Moscow, Washington, and London. The ongoing Russian attack on Ukraine is a clear warning to Belarus and Kazakhstan that these states should stay squarely within the political and military sphere of Russia's influence, or face retribution. The opening of this new era of renewed instability in Europe was sealed in 2015. In this year the resurgent Russia of imperial ambitions intervened in Syria. By now (mid-2017) the direct Russian armed involvement in the Middle East has left 35,000 people dead (in the civil war that has killed half a million; "Casualties", 2017). The Kremlin's military presence in Syria is officially justified by Moscow's heart-felt foreign relations obligation to fight 'in-

\section{- ...}

12 In 2017 Kazakhstan decided to replace Cyrillic with Latin letters for writing and publishing in Kazakh by 2025. It appears that the country, taking care not to anger the Kremlin too much, wishes to gradually leave the sphere of Russia's cultural influence (Rysaliev, 2017). 
ternational Islamic terrorism.' The Putin administration is seen as an old and trusted hand in this struggle, due to the success of the thorough suppression of the Chechen independence movement, officially labelled as 'terrorist,' in the course of two Chechen Wars of Independence. In turn, these wars radicalized tens of thousands of Chechens, who now join Islamic militants across the world, lending a degree of legitimacy to Moscow's claim about the necessity of chasing Chechen terrorists abroad. The Syrian operation also legitimizes the brand of Russia's 'managed democracy' worldwide. Russia is poised to join an international of 'electoral dictatorships' (also known as 'illiberal democracies'), as evidenced by the recent entente cordiale developing between Russia and Turkey (Applebaum, 2016; Gobry, 2016; Matthews, 2016). In addition, for the home consumption, the Russian push into the Middle East follows the logic of the half-a-millennium-old policy of the 'gathering the lands of the Golden Horde.'

On the other hand, the Russian foray into Syria brought the Kremlin's military forces into the vicinity of the Israeli frontiers. No official comments on this fact can be found, but this development could be plausibly interpreted from the perspective of the doctrine of the Russian world. After the breakup of the Soviet Union, about 1.2 million Jews left for Israel from the post-Soviet states. As a community, these Soviet Jews preserved the use of the Russian language in Israel and nowadays account for almost a quarter of the country's Jewish population of 6.5 million. On this strength alone, Israel is 'three times more' part of the Russian world than Moldova with its puny 0.5 million Russian-speakers, or even '15 times more' than Turkmenistan with its officially denied Russophone minority numbering 100,000 people. Bearing in mind the presence of this sizeable Russian-speaking minority in Israel, Moscow's military adventure in Syria ceases to appear to be an imperial folly decided in a proverbial fit of absentmindedness. On the contrary, this intervention logically follows the hardening ethnolinguistic tenets of the Russian world ideology.

Furthermore, it allows the Russian military presence to be established tantalizingly close to the Holy City of Jerusalem (cf Melman, 2017; Stesin, 2017). Apart from the fond memories of the Soviet Union and the Russian Empire, alongside Russian language and culture, the legitimacy of power in post-Soviet Russia is steeped in the Putin administration's close alliance with the Orthodox Church, represented by the Patriarch of Russia and All Rus'. Russia is the world's largest Orthodox state, both in a cultural and political sense. The Moscow Patriarchate, as its head's official title announces, corresponds more closely to Mr Putin's ideal of the Russian world than today's Russia and the Moscow-led EAEU. This Patriarchate's ecclesiastical territory encompasses all the post-Soviet states, alongside Mongolia, China, and Japan. Hence, a growing closeness of the Russian world to Jerusalem also boosts the overall legitimacy and prestige of the Moscow Patriarchate (Buciora, 2017; "List", 2017).

The ideological and territorial intertwining of the Kremlin's Russian world with the Moscow Patriarchate explains the visceral opposition of both to the post-Soviet revival of the Ukrainian Orthodox Church, which is independent of the Moscow Patriarch's jurisdiction. In a way, the Moscow Patriarchate is more successful in retaining its influence in Ukraine than the Kremlin itself. Almost a quarter of Ukraine's Orthodox faithful pledge ecclesiastical allegiance to the Moscow Patriarch vis-à-vis the country's 41 per cent Orthodox Christians (or a quarter of the country's inhabitants) who side with the Ukrainian Orthodox Church. The latter Church, however, is split between the Kyiv Patriarchate and the Ukrainian Autocephalous Orthodox Church, which keeps a third of the Orthodox faithful from formally committing to any of these patriarchates or churches. 
As a result, the most important monastery complex of Rus' or East Slavic Orthodoxy, namely the Pechersk Lavra in Kyiv, remains under control of the Moscow Patriarchate. Logically and most beneficially for Ukraine, this sacred site in the country's capital should be overseen by the Ukrainian Orthodox Church. Disunity-be it of temporal or ecclesiastical character-opens a window of opportunity for the Russian aggressor. In 2013 the Kremlin lost control of Ukraine, but the Moscow Patriarch retains his jurisdiction over the ecclesiastical heart of Kyiv and 15 per cent of Ukrainians. Meanwhile, with the Russian annexation of Crimea, the Kremlin firmly brought within the boundaries of Russia and of the Moscow Patriarchate the place where in 988 the Rus' Khagan had been baptized in Chersonesus (today, in Sevastopol). This constitutes not only a territorial gain, but also an ideological coup for the caesaropapist union between Mr Putin and the Moscow Patriarch.

The politics of historical memory employed for legitimizing present-day political projects is a slippery slope. Two years before the annexation of Crimea, Mr Putin upped the ante by decreeing that as of 2012, the beginning of Russian statehood would be celebrated in the north Russian city of (Veliky) Novgorod. In this year the 1150th anniversary of Russia was duly celebrated there in memory of the establishment of this city in 862 by the Norseman Rurik. He founded the eponymous Rurik Dynasty, which built and ruled over the medieval polity of Rus'. Until the Kremlin's 2012 intervention, Russian historiography identified the beginning of Rus' as a proper polity with Rurik's successor, Oleg, who extended the realm southward. In 882, Oleg captured Kyiv and made this city into the capital of Rus'. Before 2012 Russian history textbooks invariably saw this year as the actual beginning of Russian statehood. That is why in the $19^{\text {th }}$ century Russian historians even coined the anachronistic name "Kievan Rus"" for referring to this huge medieval polity. However, after the breakup of the Soviet Union, Kyiv found itself outside Russia. Admitting that the statehood of all modern states, which share the common heritage of Rus' commenced in Kyiv is unacceptable to today's Kremlin. Mr Putin's Russia must be number one in all spheres vis-à-vis the other post-Soviet Slavophone countries, including the oldest historical origins of the state.

\section{THE HYBRIDITY OF HARD CURRENCY}

The undeclared casus belli in the case of the recent Russian 'hybrid non-attacks' on Georgia and Ukraine was the two countries' successful efforts to sign and ratify association agreements with the European Union (EU). The Kremlin leaned heavily on both Tbilisi and Kyiv to declare their agreements null and void. Moscow also seeks the very same end by destabilizing ('hybridizing') the political situation in Moldova, as yet without resorting to the use of naked military force. The Putin administration wants the three post-Soviet countries to join the EAEU. If Georgia, Moldova, and Ukraine are not stopped in their tracks and successfully join the EU (let alone NATO), this development would rattle the legitimacy of Russia's EAEU and even shatter the dream of a unified Russian world. In June 2017 it came as a shock both to the Kremlin and the Russian public opinion that the EU waived the visa requirement for Ukrainians ("Ukrainians celebrate", 2017). ${ }^{13}$ Now Ukrainian citizens can roam freely from Lisbon to Vilnius, and from Stockholm to Rome.

13 A quarter earlier, in March 2017, also Georgian citizens were allowed to travel to the European Union without visas (cf "Georgian citizens", 2017). 
The same privilege is still withheld from the culturally and historically western-oriented Russians, due to Moscow's anti-western policies and actions during the last decade. ${ }^{14}$

It is unbelievable to many a Russian that at present a 'provincial' Ukrainian may go on a trip to Paris without the indignity of having to secure a visa. This is a direct blow to the legitimacy of Putin's foreign policy. Repercussions followed swiftly, first of all, the massive Russian cyberattack on Ukraine on the eve of the country's Constitution Day of 28 June 2017. Chillingly, this attack was heralded by the successful assassination of Colonel Maksym Shapoval, Head of the Special Forces of Ukraine's Military Intelligence. It is another from the series of politically motivated assassinations (most probably planned and perpetrated by Russia's secret service) in Kyiv after the ousting of the pro-Russian Yanukovych administration (McKew, 2017; Peleschuk, 2017). The Kremlin conveys the message that it can do as it wishes in the Ukrainian capital or actually anywhere on the Ukrainian territory. This real threat may cow numerous highly qualified specialists with skills of utmost importance for the defense of Ukraine to keep a low profile or even to emigrate.

What counts more to Mr Putin than the pro-EU wishes of the populations concerned in Georgia, Moldova, and Ukraine is a geopolitical plan that the Kremlin adopted. This holds true at least as long as the 'hybrid conflicts' can be fought on the cheap, or at best at the expense of the countries under Russian attack. As the Panama Papers indicate, the legitimacy of Mr Putin's power at the very pinnacle of his inner circle is staked on the secretive extralegal redistribution of huge financial flows among personal confidantes and top civil servants (L. Harding, 2016; Wile, 2017). The monies are duly provided by oligarchs. The Kremlin bought their loyalty with the most lucrative companies and branches of the Russian economy, which were passed to these oligarchs after 1991. The unaccountedfor income thus generated is employed for buttressing the power structure as it obtains now in Russia, and for the ad hoc plugging of holes, which may appear in the country's overstretched budget (Dawisha, 2014; Gray, 2017). Any prolonged military expense could unbalance and even bring down this shaky structure (Holslag, 2015; Kelly, 2014).

Russia with its GDP of $\$ 1.3 \mathrm{bn}$ is a middling power that politically punches way above its weight. The Russian Federation cannot compare with the Soviet Union that economically and militarily could and did challenge the United States. The Russian GDP is equal to that of Australia, which has a population one-seventh of Russia's 144 million inhabitants. It is also just twice the size of Switzerland's GDP, a country with a populace one-sixteenth that of Russia. Tellingly, Israel's GDP is only four times smaller than the Russian counterpart, though in the per capita terms it is four times bigger. If the Russian GDP is divided by the country's territory, it shows that Moscow has a mere $\$ 75,000$ to spend per square kilometer, compared with Israel's $\$ 11,254,000$, which is 150 times more. In addition, Russia's economy is over-reliant on the extraction of oil, gas, and anthracite that accounts for two-thirds of the country's exports. Any change in the price of oil may reset the entire Russian economy from one day to another. The situation is not conducive to socio-economic stability and, by extension, political stability. For the time being, the Russian system of 'managed democracy' with inbuilt elements of legal and extralegal arbitrariness appears to lend a modicum of necessary stability to the country and the Putin administration. Nationalism and the renewed imperial jingoism stoked up by successful war operations abroad coax the Russian population at large to acquiesce to the current

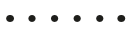

14 A fear is that Moscow may retaliate and impose visas on Ukrainian citizens who now can also travel freely across the CIS countries. However, in light of the ongoing Russo-Ukrainian war in eastern Ukraine, perhaps, this sacrifice is well worth paying. Maybe Kyiv should even take the upper hand in this field and introduce visa requirement for Russian and other CIS countries' citizens to enter Ukraine. 
political situation, including the worsening standard of living caused by the 2014 nosedive in the oil price. Patriotism requires some sacrifices.

\section{WAR IS GRATIS}

Each of the Kremlin's three successive military conflicts with Moldova, Georgia, and Ukraine that paved the way for the now popular buzz word of 'hybrid war' was either or still is fought outside Russia. None of the three countries under Russian attack have the capacity to bring warfare to the Russian territory. The now foregone hope was, after the end of communism, that the Kremlin would relent and Russia would change into a 'normal democratic' country with no imperial ambitions. On the other hand, neither Tbilisi nor Kyiv has considered emulating Chechen-style counterattacks that brought the realities of the brutal Russo-Chechen conflict to Russia's cities and towns with ethnically Russian (Slavophone and Orthodox) populations. Chișinău, Kyiv, and Tbilisi have moral qualms that typically are not shared by the Russian government when it decides to launch an attack.

That is why the wars in Moldova, Georgia, and Ukraine have been rather inexpensive for Russia, unlike the civil war in Chechnya. In the last case, the amount of materiel and the number of soldiers deployed for defeating the Chechens almost brought about a nearcollapse of the Russian economy. The economy was at its most vulnerable during the unsteady transition from central planning and full state ownership to Mr Putin's kleptocratic capitalism run by oligarchs. Even nowadays the cost of reconstructing Chechnya and bankrolling Ramzan Kadyrov's even more kleptocratic and arbitrary personal rule constitute a serious drain on Russia's budget ("Chechen leader's MMA empire", 2017). This clear financial and economic constraint prevents Russia from engaging in a traditional kind of warfare that involves deployments of hundreds of thousands of soldiers into action and subsequently keeping them in place for the long-term occupation of annexed territories. For the time being, the Kremlin must do with scarce 'volunteers' (including sentenced criminals and gang members) pushed into 'patriotic duty' by propaganda, or more frequently by inadequate pay and lack of gainful employment in Russia (Kostyuchenko, 2015; "Little green men", 2017; "Russian soldiers", 2015).

With regard to the war in Moldova, the main expense for the Kremlin has been that of the Soviet-turned-Russian army stationed in breakaway Transnistria. Moscow, in line with the doctrine of near abroad, has never had any intention of withdrawing this army. The budgetary item for its maintenance was kept seamlessly between Soviet and Russian budgets. The troops have been a significant instrument for extending and maintaining Russian military presence in this far-flung corner of Russia's near abroad. What is more, without any additional cost, this Russian army in Transnistria endangered Ukraine's struggle against the Russian invasion in the east of the country. If the Ukrainian military forces turn out to be too successful on the eastern front, the Russian troops stationed in Transnistria may launch a 'liberating attack' on Odesa (cf Lake \& Rogin, 2014), where the population express substantially more sympathy for Russian language and culture than in western and central Ukraine. When the majority of Ukrainian soldiers are engaged in the east, the Russian army would have a good chance to push from Transnistria as far as Crimea, cutting Ukraine off the Black Sea littoral. A possible Ukrainian reaction in the form of a shift of some Ukrainian forces from the east to the west, could in turn enable the Russian occupying forces in eastern Ukraine to commence a westward offensive for 
capturing the intervening Sea of Azov littoral between the occupiers' current positions in Novozaovs'k and Crimea. In such a scenario Kyiv would lose as much as 25 per cent of the state's territory. Overnight Ukraine would become a landlocked country (like Belarus), with the two-thirds of its frontiers facing restive Russia.

But when the Kremlin waged war against Georgia in 2008, Moscow actually had to send Russian troops abroad for the first time ever in the European post-Soviet world. As with the case of Moldova, the intention was to establish a permanent military presence in the near abroad. To this end, in 2008 Russian bases were founded in Abkhazia or South Ossetia; a move that entailed substantial financial outlays. The step was viable, because the oil price stood at its apogee of $\$ 130$ per barrel. The two territories had been seized from Georgia and made into de facto polities. In a unilateral manner Russia recognized the independence of these two breakaway regions that ethnically are non-Georgian and non-Russian. Then the Kremlin had to face the economic reality of its military adventurism, which among other factors, contributed to the tumbling down of the price of oil to a mere $\$ 50$ by late 2008 .

Moscow did not follow this route of formal state recognition in Transnistria, which is overwhelmingly Russian (Russophone). The option of either recognizing Transnistria as an independent country or incorporating this territory into Russia remains open, the exclave of Kaliningrad being a possible model. As such this equivocation affords the Kremlin a useful leverage on Moldova. In reality, all the three aforementioned separatist territories are de facto states that double as second-class Russian regions. Their economies can (barely) function, only thanks to the steady flow of cash, aid, and (usually heavily subsidized) business from Russia itself. These territories' inhabitants need Russian passports to travel abroad, the three de facto states' documents valid only internally, and of no official value even in Russia. By the way, the same is true of Russian internal IDs issued in Crimea. On their basis, one cannot apply for a loan in a Russian bank. Russia's financial institutions take care not to cross the red line in order not to be cut off the international system of finances. Without the possibility of moving capital swiftly across the globe, no commercial bank in Russia can count on generating reasonable profit.

In comparison to the ongoing Russian war against Ukraine, the conflict is considerably cheaper for the Kremlin, though it involves substantially more territory and population. It cannot be otherwise, this war must be fought on the cheap, because the oil price hit a new low of $\$ 29$ per barrel in early 2016. The standard of living that grew quite rapidly in Russia during the preceding decade came tumbling down as well. In its stead, wartime jingoism and the 'victory' of annexing Crimea kept Mr Putin's popularity ratings up. This is the distinctive feature of hybrid war in its pure form: its cheapness for the aggressor and the staggering expense in financial, economic, or social terms for the country under attack. The media usually overlook this crucial feature and prefer to define hybrid war by focusing on colorful propaganda and untruths designed to conceal the actual nature of such a conflict from outside and internal observers alike. Due to information overload packaged in attractive images (often courtesy of Photoshop), hybrid war appears to onlookers as though another virtual reality computer game. This kind of propaganda-spread across the world by Moscow's multilingual Sputnik and Russia Today news outlets, and buttressed by farms of social media trolls in the state's pay (Chen, 2015; Pollock, 2017)_ makes the global public opinion forgetful to the hard facts of 15,000 casualties and counting in Ukraine, alongside 1.6 million refugees from the warzones under Russian attack in this country. 
The sole tangible financial outlay that the Kremlin made during the current RussoUkrainian war is that on the ongoing construction of the bridge that would span annexed Crimea with Russia over the Kerch Strait. The bridge is scheduled to open in 2019. In addition, the peninsula's population was partly absorbed into the Russian system of social provisions. However, the flow of water supplied to Crimea from Ukraine was not seriously reduced until late 2015, while electricity still goes to the peninsula unobstructed. All this is quite inexplicably in the time of war. As a result, Ukraine continues subsidizing Russia's annexation of Crimea, instead of forcing Russia to shoulder the entire burden of providing the region's over 2 million inhabitants with indispensable water and electricity. When the Kerch bridge has been opened, the Kremlin will not fail to announce another victory, the victory of achieving full energy and water independence from Ukraine. Meanwhile, Kyiv buys most of its oil and gas from Russia, affording the Kremlin a simple instrument of garroting the Ukrainian economy and population when the Ukrainian troops are too successful at fending off Russian attackers (cf "Battle of Ilovaisk", 2017; Peterson, 2017). In the course of the current war, the Kremlin already cut off gas supplies to Ukraine twice, in June 2014 and November 2015 (cf "Battle of llovaisk", 2017; Peterson, 2017).

A similar situation of Ukraine subsidizing Moscow's military aggression can be observed in Luhansk and Donetsk provinces under Russian occupation. Although Kyiv periodically stops the supply of electricity to the two breakaway 'republics,' both remain connected to the country's power grid. In the time of such brief stoppages Russia flexes its propaganda muscle and sends electricity to Luhansk and Donetsk. It is an expense not worth mentioning, because for most of the time it is Ukraine that continues providing power in exchange for anthracite from the Donetsk and Luhansk mines. In addition, through a variety of ad hoc arrangements Kyiv keeps paying pensions to the separatist republics' rapidly aging population (most youth with marketable qualifications left either for Ukraine or Russia). However, at times pensioners have to make a perilous journey across the frontline to unoccupied Ukraine in order to withdraw their pensions from a working ATM machine.

The Ukrainian government may claim that it cannot take a more decisive stance on these issues because Ukrainian society is divided in this respect. As many as 70 per cent of Ukrainians believe that peace must be reestablished in eastern Ukraine only on the basis of a mutually acceptable compromise. Although more than half of the Ukrainians agree that eastern Ukraine finds itself under Russian occupation, as few as 18 per cent of them would agree to the liberation of these territories with the use of military force. Almost two-thirds of Ukrainians think that inviting an international peacekeeping force would be a step in the right direction, while a third trusts that international pressure on Russia alone would do the job. At the same time, 60 per cent of Ukrainians want the population in the occupied areas to have access to Ukraine's educational and welfare systems (Hromads'ka dumka, 2017). The confused picture shows that without a principled leadership and without a clear line of action, the conflict in the east is poised to drag on for years or even decades to come. This is Moscow's hope that Ukraine may be kept down with Ukrainian hands and at the country's own expense.

\section{BETWEEN PATRIOTISM AND OLIGARCHS}

Year in and year out, thousands of volunteers and draftees join the Ukrainian military to fight against the Russian aggression. Across Ukraine's cities, towns, and villages citizens 
collect donations for the cash-starved Ukrainian army. Recruitment and donation points, alongside churches and many a town square display photographs of Ukrainian soldiers killed and missing in action. The chilling everyday reality of the war is also depicted by photographs of generalized destruction wreaked by the conflict. Day after day, each Ukrainian news bulletin and newspaper invariably opens with information on the front, casualties, the wounded and displaced (cf Knyha pam'iati, 2017; "Polehli biĭtsi ATO", 2017).

The continuing tragedy of this war is deepened by the persistent denial of a proper name to the conflict. The Kremlin claims Russia is not involved, while Kyiv sanitizes the reality on the ground by dubbing this war 'ATO,' or the Anti-Terrorist Operation ("Terytoriia", 2017). A non-war ATO, indeed. But to those fighting and stranded in the warzone, shelling and shooting, death and destruction are nothing else but war. They know no other word for describing what is happening in front of their eyes, in their backyards and apartments scarred by mortar fire. It is war.

Russia shirks from recognizing this war for the fear of becoming an internationally acknowledged aggressor, a pariah of international relations. The EU has no intention to see the conflict acknowledged as a war, preferring the term 'crisis' ("EU sanctions", 2017; "The EU's response", 2017), because it is easier to import Russian oil and gas than to become energetically independent. This attitude yields the oft-repeated slogan that 'we have to talk to Russia,' that the Kremlin must not be alienated for whatever international wrongdoings it may be guilty of. Perhaps, this explains why the unpalatable reality of the Russo-Ukrainian war is not (or only rarely) reported in the EU countries' mass media, including Poland, Slovakia, Hungary, and Romania that directly border on Ukraine-as though the wave of well over one million Ukrainians who arrived to the countries during the last years despite the onerous visa restrictions had nothing to do with the RussoUkrainian war. Western media tire of reporting warfare rather soon, especially when no US, British or other western soldiers are involved.

Young male and female Ukrainian soldiers valiantly defending their country on the eastern front are not helped by the west's odious equivocation on this subject. Their wounds and deaths are for real. How do they feel that at the same time Ukrainian oligarchs and oligarchs-turned-politicians continue trading with Russia and the occupied territories as if nothing has happened? As if there were no war. These oligarchs and politicians with vested economic interests either tone down or out of hand reject any proposals of the full economic and financial isolation of the territories occupied by Russia. In September 2014, after Russia's seizure of Ukraine and the eruption of fighting in eastern Ukraine, Kyiv decided to build a border wall along Ukraine's almost 2000-kilometer-long land frontier with Russia ("Ukraine-Russia", 2017). Due to the occupation of Luhansk and Donetsk provinces Russia effectively controls a quarter of this boundary. However, after constructing about 200 kilometers of the wall, the work stopped in 2017. The funds had run out. The completion deadline of 2018 will not be kept ("Ukraine runs", 2017). ${ }^{15}$ The UkrainianRussian border remains largely unguarded and unprotected, open to Russian infiltration, contraband, or human trafficking. Russian citizens can cross the frontier without the necessity of applying for a Ukrainian visa (Petrov, 2017a; "Ukraine bans Russians", 2015; "Ukraine's new border restrictions", 2017). As though Russia did not attack Ukraine and were a friendly country. As if Ukraine has already become part of the Russian world.

15 However, in August 2017 the news is that Kyiv persists in its effort to complete the border wall ("Ukraine bans its top social networks", 2017). 
The Ukrainian President Petro Poroshenko's Roshen confectionary company with the annual revenue of $\$ 1$ billion has factory shops in most Ukrainian cities and towns. Quite an unusual feat for any confectionary company, let alone in a country in the state of war. Even more damningly, despite the early 2017 promise to close down the company's Russian factory in Lipetsk, Roshen continues to retain its economic and commercial presence in enemy territory. Mr Poroshenko claims that it is the Putin administration who does not permit him to stop production at this plant. But in reality there is nothing preventing him from abandoning the plant without lowering himself to any squabble with Moscow on legal niceties ("Zakrytie", 2017). Mr Poroshenko is unable to decide what is more important for him-the Presidency of Ukraine or owning and managing his confectionary empire. He has not decided yet, though his five-year term in office comes to an end in 2019. In the time of war trading with and maintaining personal economic presence in Russia appears dangerously close to an act of treason. Widening a network of his own confectionary shops in Ukraine, which is fighting a war against authoritarian and neo-imperialist Russia is an utmost folly. The territorial integrity of Ukraine is at stake. And, even more importantly, whether Ukraine is going to become a modern, democratic, and prosperous state run in accordance with the rule of law, as demanded by the Revolution of Dignity. Then the Ukrainians' utmost dream could be fulfilled, of their country's membership in the European Union and NATO. Thus far thousands of Ukrainians have sacrificed their very lives for this dream. So their children at long last could live in a 'normal country.' Poroshenko by continuing to use his political clout for propping up the Roshen Company opens himself to the accusation of being guilty of a blatant conflict of interests.

No statesman worthy of note was ever a businessman. Neither Abraham Lincoln, nor Winston Churchill, nor Konrad Adenauer, nor Indira Gandhi. Can we imagine Churchill leading an effective war against the German aggressor, if he had been more concerned about his hypothetical network of convenience shops in Britain and Germany? Had he had to choose between launching an attack on Berlin, or keeping his shops in Bavaria? A laughable and incongruent impossibility. Yet, this is the reality of Ukraine's economy and politics. Politicians bowing to their personal economic interest, with no respect for the dignity of their offices or for the wishes of their electorates do not auger well for Ukraine. At the country's helm is a person stands who may still decide that his company is dearer to his heart than Ukraine. In Russia, it is crystal clear that Mr Putin controls and uses Russia's oligarchs, as he sees fit, not the other way around.

Should Mr Poroshenko choose his company over Ukraine and lower himself to the unbecoming status of an oligarch, he may easily fit in the oligarchic system that the Kremlin aspires to export across the Russian world. The system's center is located in Moscow. The Russian leader has an obvious advantage over the current Ukrainian President: $\mathrm{Mr}$ Putin prefers to be President of Russia, while oligarchs are his underlings. As a result, the Russian President cuts a more charismatic figure, evoking loyalty across the whole spectrum of the Russian population. On the contrary, hardly any Ukrainian soldier can be truly inspired by Mr Poroshenko the oligarch, though officially he is known as President of Ukraine. Mr Poroshenko's ambiguous stance not only mars the gravitas of this office, but weakens the Ukrainians' resolution to fend off the Russian aggression. If their President, despite delivering rousing speeches, in reality cares more for his own profits, why should an average Ukrainian citizen give up their personal well-being or happiness, let alone life, in service of their country? 
In order to be able to lead Ukraine through this difficult time of war to a future of peace and prosperity, Mr Poroshenko ought to channel any profits gained from his company after becoming President in 2014 for the sake of war effort. He must give up his company to the state after securing sufficient (but not ostensible) funds for his family. Otherwise, the Ukrainian President's pronouncements announcing that Ukraine's future lies in the EU and NATO will remain hollow words devoid of meaning. For God's sake, young Ukrainian women and men are dying in the east not for sweets, peanuts or, let alone, the Roshen Company.

Has the President noticed? Who's going to tell him?

Through the mass media and via the internet many Ukrainians have expressed time and again their dismay at Mr Poroshenko's harmful vacillation. Numerous members of the Verkhovna Rada (Ukraine's Parliament) berate him on this account, alongside Brussels and NATO. But Mr Poroshenko keeps his options open, blaming this unprincipled stance he took on the Russian military aggression. The pressure does not work. Pesky opponents in the Parliament can be bought or turned around with a political favor. Ukraine's civil society keeps operating in a bubble of its own organizations and publications without a clear way to translate its considerable energy and desire for change into a tangible political action. The west is easily distracted and pays way too little attention to the difficult process of democratization in Ukraine or to the Russo-Ukrainian war. The unarticulated suspicion is that many western European governments continue in their unwise proclivity not to treat Ukraine seriously. This is a dangerous political myopia that plays directly into Russia's hands. Mr Poroshenko's indecision worsens this tendency. ${ }^{16}$ The social capital and support for change, as generated during the Revolution of Dignity, is abused and carelessly wasted.

This is high time to wake up.

\section{REFERENCES}

About Ruskiyi Mir Foundation. (2017). Retrieved August 8, 2017, from http://russkiymir. ru/en/fund/

Applebaum, A. (2016, August 11). Erdogan, Putin and the strongman ties that bind. The Washington Post. Retrieved August 8, 2017, from http://www.washingtonpost.com/ opinions/global-opinions/erdogan-putin-and-the-strongman-ties-that-bind/2016/08/11/ ab0fe27a-5fdc-11e6-af8e-54aa2e849447_story.html?utm_term=.14734a9e567d

Babaeva, F. (2016, June 15). Turkmenistan, China to boost cooperation in oil \& gas sector. Azernews. Retrieved August 4, 2017, from https://www.azernews.az/region/98031. html

Bailey, S. D., \& Daws, S. (1995). The United Nations: A concise political guide. Basingstoke: Macmillan. https://doi.org/10.1007/978-1-349-23753-1

16 Some could say that my criticism of Mr Poroshenko is too harsh, if not unjust. But it is impossible to deny the facts as they are, unless I err somewhere in the analysis. Obviously, should the United States be seen as the beacon of democratic standards, the 2016 election of Mr Donald Trump the billionaire to the post of the US President can be interpreted as a novel carte blanche in the democratic world for disregarding any conflict of interests between elected office and business (cf Venook, 2017). But the US is not waging a war for survival as a state. Ukraine is, and simultaneously aspires to join both the EU and NATO. Hence, Ukraine cannot afford a single slip in standards at the highest level of power. Because ultimately it may cost the Ukrainians the loss of their statehood, alongside the capacity to decide about their own future as a nation. 
Battle of llovaisk. (2017). In Wikipedia. Retrieved August 8, 2017, from http://en.wikipedia. org/wiki/Battle_of_llovaisk

Berezovets, T. (2015, July 23). Putin's purge of Crimean dissidents continues apace. Newsweek. Retrieved August 4, 2017, from www.newsweek.com/putins-purge-crimean-dissidents-continues-apace-356628

Bershidsky, L. (2017, May 17). Why Ukraine said 'nyet' to Russian social networks. Bloomberg View. Retrieved August 8, 2017, from http://www.bloomberg.com/view/ articles/2017-05-17/why-ukraine-said-nyet-to-russian-social-networks

Brzezinski, Z. (2017). On the USSR and Russia. In In Memoriam: Zbigniew K Brzezinski: A life of service and strategy. Retrieved July 18, 2017, from http://www.csis.org/features/zbigniew-k-brzezinski

Buciora, J. (2017). Canonical territory of the Moscow Patriarchate: An analysis of contemporary Russian Orthodox thought. Retrieved August 8, 2017, from www.orthodoxchristian-comment.co.uk/canonical_territory_of_the_moscow_patriarchate.htm

Casualties of the Syrian Civil War. (2017). In Wikipedia. Retrieved August 8, 2017, from http://en.wikipedia.org/wiki/Casualties_of_the_Syrian_Civil_War

Chechen leader's MMA empire: A tool for propaganda and more. (2017, July 31). Retrieved August 8, 2017, from www.npr.org/2017/07/31/540652582/chechen-leaders-mma -empire-a-tool-for-propaganda-and-more

Chechen official puts death toll for 2 wars at up to 160,000. (2005, August 16). The New York Times. Retrieved August 4, 2017, from www.nytimes.com/2005/08/16/world/europe/chechen-official-puts-death-toll-for-2-wars-at-up-to-160000.html

Chen, A. (2015, June 2). The Agency. The New York Times. Retrieved August 8, 2017, from http://www.nytimes.com/2015/06/07/magazine/the-agency.html

Cheterian, V. (2009). The August 2008 war in Georgia: From ethnic conflict to border wars. Central Asian Review, 28(2), 155-170. https://doi.org/10.1080/02634930903056768

Chupryna, I. (2014). The Orange Revolution and the Revolution of Dignity: Similarities and differences. (DPC Policy Note New Series, 6). Retrieved August 8, 2017, from http:// www.democratizationpolicy.org/pdf/DPC\%20Policy\%20Note \%20New\%20Series \%20 $6 \% 20$ Ukraine\%27s\%20Revolutions.pdf

Dal Santo, M. (2015, July 16). Revealing the Post-Soviet identity complex in Transnistria. Russia Direct. Retrieved August 4, 2017, from www.russia-direct.org/qa/revealingpost-soviet-identity-complex-transnistria

Dawisha, K. (2014). Putin's kleptocracy: Who owns Russia? New York, NY: Simon \& Schuster.

Dempsey, J. (2014, January 20). Time to pull together on Ukraine. Retrieved August 8, 2017, from http://carnegieeurope.eu/strategiceurope/54245?lang=en

Donaldson, J. (1877). Atrocités Russes en Asie et en Roumelie pendant les mois de Juin, Juillet et Aout 1877. Retrieved from http://ubsm.bg.ac.rs/engleski/dokument/1844/ atrocits-russes-en-asie-et-en-roumlie-pendant-les-mois-juin-juillet-et-aout-1877

EU sanctions against Russia over Ukraine crisis. (2017). Retrieved August 8, 2017, from http://europa.eu/newsroom/highlights/special-coverage/eu-sanctions-against-russiaover-ukraine-crisis_en

The EU's response to the crisis in Ukraine. (2017). Retrieved August 8, 2017, from www. eppgroup.eu/our-priority/The-EU's-response-to-the-crisis-in-Ukraine 
Frelick, B. (1994). Faultlines of nationality conflict: Refugees and displaced persons from Armenia and Azerbaijan. International Journal of Refugee Law, 6(4), 581-619. https:// doi.org/10.1093/ijrl/6.4.581

Georgian citizens can travel to the Schengen Zone without a visa. (2017, March 27). Retrieved August 4, 2017, from http://www.schengenvisainfo.com/georgian-citizens-cantravel-to-the-schengen-zone-without-a-visa/

Gil'ferding, A. F. (2010). Kogda Evropa byla nasher: Istoriia baltī̌skikh slavian. Moskva: Algoritm.

Gobry, P.-E. (2016, September 14). Vladimir Putin is trying to take down liberal democracy-and he might be winning. The Week. Retrieved August 8, 2017, from http://theweek.com/articles/648449/vladimir-putin-trying-take-down-liberal-democracy--mightwinning

Gray, R. (2017, July 25). Bill Browder's testimony to the Senate Judiciary Committee. The Atlantic. Retrieved August 8, 2017, from http://www.theatlantic.com/politics/archive/2017/07/bill-browders-testimony-to-the-senate-judiciary-committee/534864/

Grier, P. T. (2003). The Russian idea and the West. In R. Bova (Ed.), Russia and Western civilization: Cultural and historical encounters (pp. 23-77). Abingdon: M. E. Sharpe.

Harding, J. (2016, June 12). Published Donbass kill ratios (aggregated) [Blog post]. Retrieved August 4, 2017, from http://toinformistoinfluence.com/2016/06/12/publisheddonbass-kill-ratios-aggregated/

Harding, L. (2016, April 3). Revealed: The \$2bn offshore trail that leads to Vladimir Putin. The Guardian. Retrieved August 8, 2017, from http://www.theguardian.com/ news/2016/apr/03/panama-papers-money-hidden-offshore

Helsinki Final Act, 1975. (2017). Retrieved August 8, 2017, from http://history.state.gov/ milestones/1969-1976/helsinki

Hentschel, G., Taranenko, O., \& Zaprudski, S. (Eds.). (2014). Trasjanka und Suržyk-gemischte weißrussisch-russische und ukrainisch-russische Rede: Sprachlicher Inzest in Weißrussland und der Ukraine? Frankfurt am Main: Peter Lang. https://doi. org/10.3726/978-3-653-05057-8

Hille, K., \& Seddon, M. (2016, September 23). Bridge to Crimea: Putin strives to complete a 'historic mission'. The Financial Times. Retrieved August 8, 2017, from http://www. ft.com/content/1c266a70-8160-11e6-8e50-8ec15fb462f4

Holslag, J. (2015, June 18). Why Russia can't afford a Cold War. Retrieved August 8, 2017, from www.jonathanholslag.be/blog/1409/

honigkuchen. (2016, October 4). Russkaia Evropa na polputi k Zapadnoĭ. Retrieved June 27, 2018, from http://irecommend.ru/content/russkaya-evropa-na-polputi-k-zapadnoi

Hromads'ka dumka stosovno nepidkontrol'noho Donbasu: Shcho zminylos'? (2017). Kyïv: Fond Demokratychni initsiatyvy imeni II'ka Kucheriva. Retrieved July 17, 2017, from http://dif.org.ua/uploads/pdf/463193043596caafee8d963.90418897.pdf

Kalb, J. E. (2008). Russia's Rome: Imperial visions, messianic dreams, 1890-1940. Madison: University of Wisconsin Press.

Katzman, K. (2003). Afghanistan: Current issues and US policy. In L. M. Buyers (Ed.), Central Asia in focus: Political and economic issues (pp. 210-242). New York, NY: Nova Science Publishers.

Kelly, L. (2014, October 7). Finance minister warns Russia can't afford military spending plan. Reuters. Retrieved August 8, 2017, from www.reuters.com/article/us-russia-economy-spending-defence-idUSKCNOHW1H420141007 
Khalidi, N. A. (1991). Afghanistan: Demographic consequences of war: 1978-87. Central Asian Survey, 10(3), 101-126. https://doi.org/10.1080/02634939108400750

Kirby, W. (2017, July 31). Trump ready to punish China for North Korea inactivity amid growing tensions with Russia. Express. Retrieved August 8, 2017, from www.express.co.uk/news/world/835022/donald-trump-us-punish-china-xi-kim-jong-un-northkorea-missile-russia-putin-cold-war

Kirsis, K. P. (2001). "Nasha Evropa": An examination of the identity of Latvia within the Soviet Union (BA Thesis). Amherst College, Amherst, MA.

Knyha pam'iati polehlykh za Ukraïnu. (2017). Retrieved August 4, 2017, from http://memorybook.org.ua/index1.htm

Kostyuchenko, E. (2015, March 25). Invisible army: The story of a Russian soldier sent to fight in Ukraine. The Guardian. Retrieved August 8, 2017, from http://www.theguardian.com/world/2015/mar/25/russia-ukraine-soldier

Lacina, B., \& Gleditsch, N. P. (2005). Monitoring trends in global combat: A new dataset of battle deaths. European Journal of Population, 21(2-3), 145-160. https://doi. org/10.1007/s10680-005-6851-6

Lake, E., \& Rogin, J. (2014, April 17). Is Putin's next move to take over Odessa? Daily Beast. Retrieved June 27, 2018, from http://www.thedailybeast.com/is-putins-next-move -to-take-over-odessa

Lakshin, O. (2016, June 11). 'Nasha Evropa' rodilas' zanovo. Retrieved August 4, 2017, from www.vesti.ru/doc.html?id=2764142

Lishka, O. (2008, July 22). Russkaia Evropa ili evropeǐskaia Rossiia? Retrieved August 4, 2017, from http://inosmi.ru/world/20080722/242764.html

List of autocephalous and autonomous churches: Map of the canonical territories of autocephalous and autonomous Orthodox jurisdictions. (2017). In Orthodoxwiki. Retrieved August 8, 2017, from http://orthodoxwiki.org/List_of_autocephalous_and_autonomous_churches

Little green men (Ukrainian crisis). (2017). In Wikipedia. Retrieved August 4, 2017, from http://en.wikipedia.org/wiki/Little_green_men_(Ukrainian_crisis)

Loza, I. (2015). Istorychnyĭ atlas Ukraïny. Kyïv: Mapa.

Luhn, A. (2017, May 16). Ukraine blocks popular social networks as part of sanctions on Russia. The Guardian. Retrieved August 8, 2017, from http://www.theguardian.com/ world/2017/may/16/ukraine-blocks-popular-russian-websites-kremlin-role-war

McCarthy, J. (1995). Death and exile: The ethnic cleansing of Ottoman Muslims, 18211922. Princeton, NJ: Darwin Press.

McKew, M. (2017, June 27). A killing in Kiev shows how the West continues to fail Ukraine. The Washington Post. Retrieved August 8, 2017, from http://www.washingtonpost.com/news/democracy-post/wp/2017/06/27/a-killing-in-kiev-shows-how-the-westcontinues-to-fail-ukraine/?utm_term=.9ea2d9e722b6

McLaughlin, D. (2017, January 8). Ukraine targets NATO membership despite Russian warnings. The Irish Times. Retrieved August 8, 2017, from http://www.irishtimes. $\mathrm{com} /$ news/world/europe/ukraine-targets-nato-membership-despite-russian-warnings-1.3112524

Matthews, O. (2016, August 9). Erdoğan and Putin reignite the bromance. Politico. Retrieved August 8, 2017, from www.politico.eu/article/turkey-president-erdogan-and-russiavladimir-putin-reignite-the-bromance-west-failed-putsch/ 
Melman, Y. (2017, March 23). Analysis: How worried are Israel's leaders about Putin's Syrian warning? The Jerusalem Post. Retrieved August 8, 2017, from www.jpost.com/ Israel-News/Politics-And-Diplomacy/Analysis-How-worried-are-Israels-leaders-aboutPutins-Syrian-warning-484937

Moore, K. (2002, December 5). Russia: Cyrillic law ruffles feathers in republics. Retrieved June 27, 2018, from http://www.rferl.org/a/1101584.html

Moser, M. (2013). Language policy and the discourse on languages in Ukraine under president Viktor Yanukovych (25 February 2010-28 October 2012). Stuttgart: Ibidem-Verlag. (Soviet and Post-Soviet Politics and Society, 122).

Nasha Evropa: Kaliningrad. (2016, September 14). Retrieved August 4, 2017, from http:// rugrad.eu/smi/898221/

Over 200,000 killed in Chechnya since 1994 - Pro-Moscow official. (2004, November 19). MosNews. Retrieved August 4, 2017, from http://archive.is/20041120124031/http:// www.mosnews.com/news/2004/11/19/civiliandeath.shtml\#selection-1421.0-1421.64

Peleschuk, D. (2017, June 30). In Kiev, assassinations are becoming commonplace. Retrieved August 8, 2017, from http://www.pri.org/stories/2017-06-30/kiev-assassinations-are-becoming-commonplace

Peterson, N. (2017, February 12). Ukraine rebels' front line. Newsweek. Retrieved August 8, 2017, from www.newsweek.com/nolan-peterson-russian-troops-man-ukraine-rebels -front-line-555141

Petrov, V. (2017a, August 3). Most residents of Donbas against visas with Russia. Kyiv Post. Retrieved August 8, 2017, from http://www.kyivpost.com/ukraine-politics/residents-donbas-visas-russia.html

Petrov, V. (2017b, July 21). Poroshenko: 11,000 Ukrainians killed since beginning of war in Donbas. Kyiv Post. Retrieved August 4, 2017, from http://www.kyivpost.com/ukraine-politics/poroshenko-11000-ukrainians-killed-since-beginning-war-donbas.html

Phillips, T. (2017, February 7). Donald Trump and China on dangerous collision course, say experts. The Guardian. Retrieved August 8, 2017, from http://www.theguardian. com/us-news/2017/feb/07/donald-trump-and-china-military-confrontation-dangerouscollision-course-experts

Polehli biĭtsi ATO. (2017, April 24). Unian. Retrieved August 4, 2017, from http://www. unian.ua/war/1890856-polegli-biytsi-ato-opublikovano-infografiku-de-pohovani-gerojiviyni-mij-rosieyu-ta-ukrajinoyu.html

Pollock, J. (2017, April 13). Russian disinformation technology. MIT Technology Review. Retrieved August 8, 2017, from http://www.technologyreview.com/s/604084/russiandisinformation-technology/

Poltoratzky, N. P. (1967). Nikolay Berdyayev's interpretation of Russia's historical mission. The Slavonic and East European Review, 45(104), 193-206.

Rettman, A. (2017, February 21). The Armenia-Azerbaijan war: A refugee's story. euobserver. Retrieved August 4, 2017, from http://euobserver.com/foreign/136976

Riazantsev, S. V. (2005, August 29-September 11). Posledstviia voennykh deǐstviĭ $\checkmark$ Chechenskoĭ respublike $\vee$ demograficheskom, sotsial'nom i èkonomicheskom otnoshenii. Demoskop Weekly, 2005(211-212). Retrieved August 4, 2017, from http:// demoscope.ru/weekly/2005/0211/analit02.php

Richmond, W. (2013). The Circassian genocide. New Brunswick, NJ: Rutgers University Press. 
Rudnytsky, I. L. (1987). Essays in modern Ukrainian history. Retrieved August 8, 2017, from www.ditext.com/rudnytsky/history/title.html

Russkaia Evropa: Russkie i russkoiazychnye v Evrope. (2017). Retrieved August 4, 2017, from http://russian-world.info/russkaya-evropa/

Russians 'flee' Turkmenistan. (2003, June 20). Retrieved August 4, 2017, from http:// news.bbc.co.uk/1/hi/world/asia-pacific/3007598.stm

Russian soldiers quit after being sent to fight in Ukraine: Report. (2015, May 10). New York Post. Retrieved August 8, 2017, from http://nypost.com/2015/05/10/russian-soldiers-quit-after-being-sent-to-fight-in-ukraine-report/

Russo-Georgian war: Casualties and losses. (2017). In Wikipedia. Retrieved August 4, 2017, from http://en.wikipedia.org/wiki/Russo-Georgian_War

Rysaliev, A. (2017, April 12). Kazakhstan: President calls for switch to Latin alphabet by 2025. Retrieved August 4, 2017, from www.eurasianet.org/node/83206

Semenovich, A. (2016, March 28). Seeking shelter: Russia's refugees from Eastern Ukraine, 2 years on. Retrieved August 4, 2017, from http://www.rbth.com/politics_and_ society/2016/03/28/seeking-shelter-russias-refugees-from-eastern-ukraine-2-yearson_579789

Sergei Naryshkin: The creation of the Eurasian Economic Union requires the support of all of Russkiy Mir. (2012, June 20). Retrieved August 8, 2017, from http://pm.pф/en/ news/129190/

Soldak, K. (2014, August 23). In a time of war and recession, Ukraine's independence is more important than ever. Forbes. Retrieved July 17, 2017, from http://www.forbes. com/sites/katyasoldak/2014/08/23/in-a-time-of-war-and-recession-ukraines-independence-is-more-important-than-ever/\#717fc68a2039

Solov'ev, S. (2017). Ob istorii drevneĭ Rossii. Moskva: Dorfa.

Sorbello, P. (2017, April 25). Turkmenistan's ongoing gas quandary. The Diplomat. Retrieved August 4, 2017, from http://thediplomat.com/2017/04/turkmenistans-ongoing-gasquandary/

Stesin, L. (2017, April 2). Could Israel's actions mean Russian Jews end up as Putin's hostages? Haaretz. Retrieved August 8, 2017, from http://www.haaretz.com/opinion/. premium-1.780186

Strade, N. (2005, June 26). Aljazeera: 'Official': Chechen wars killed 300,000. Retrieved August 4, 2017, from http://groups.yahoo.com/neo/groups/chechnya-sl/conversations/ topics/45015

Terytoriia provedennia antyterorystychnoï operatsiï. (2017). In Vikipediia. Retrieved August 8, 2017, from http://uk.wikipedia.org/wiki/Територія_проведення_антитерористичної_операції

TSutsiev, A. (2007). Atlas étnopoliticheskoĭ istorii Kavkaza (1774-2004). Moskva: Izdatel'stvo Evropa.

TSygankov, A. P. (2007). Putin and foreign policy. In D. R. Herspring (Ed.), Putin's Russia: Past imperfect, future uncertain (pp. 194-217). Lanham, MD: Rowman \& Littlefield.

Ukraine bans its top social networks because they are Russian. (2017, May 19). The Economist. Retrieved August 4, 2017, from http://www.economist.com/news/europe/ 21722360-blocking-websites-may-be-pointless-it-could-help-president-poroshenkospopularity-ukraine

Ukraine bans Russians from entering on internal documents. (2015, February 3). Ukrainskaya Pravda. Retrieved August 8, 2017, from http://meduza.io/en/news/2015/02/03/ ukraine-bans-russians-from-entering-on-internal-documents 
Ukraine: Global focus. (2017, July 17). Retrieved August 4, 2017, from http://reporting. unhcr.org/Ukraine

Ukraine may spend UAH 500 mln on wall on border with Russia in 2017. (2017, August 7). Interfax. Retrieved August 8, 2017, from http://en.interfax.com.ua/news/general/440792. html

Ukraine runs out of money to build wall on Russian border. (2017, January 20). Retrieved August 8, 2017, from http://www.rbth.com/news/2017/01/20/ukraine-runs-out-of-money-to-build-wall-on-russian-border_685548

Ukraine-Russia border fence / European bulwark. (2017, January 2). Retrieved August 8, 2017, from www.globalsecurity.org/military/world/ukraine/border-fence.htm

Ukraine's new border restrictions regarded as 'new Berlin Wall': Russian FM. (2017, July 12). Xinhuanet. Retrieved August 8, 2017, from http://news.xinhuanet.com/english/201707/12/c_136436261.htm

Ukrainians celebrate visa-free travel to EU. (2017, June 11). Retrieved August 4, 2017, from http://www.rferl.org/a/ukraine-poroshenko-eu-visa-free-goodbye-ussr/28539873. html

Unlikely partners. (2017, July 29). The Economist, 51-52.

Velychenko, S. (2013, December 30). Ukraine: The world's last big colony and the EU left. Retrieved August 8, 2017, from www.newleftproject.org/index.php/site/article_comments/ukraine_the_worlds_last_big_colony_and_the_eu_left

Venook, J. (2017, August 4). Trump's interests vs. America's, Secret Service Edition. The Atlantic. Retrieved August 8, 2017, from http://www.theatlantic.com/business/archive/2017/08/donald-trump-conflicts-of-interests/508382/

Vsesoiuznaia perepis' naseleniia 1989 goda: Natsional'nyı̆ sostav naseleniia po regionam Rossii. (n.d.). Retrieved August 4, 2017, from www.demoscope.ru/weekly/ssp/rus_ nac_89.php?reg=49

Wile, R. (2017, January 23). Is Vladimir Putin secretly the richest man in the world? Time. Retrieved August 8, 2017, from http://time.com/money/4641093/vladimir-putin-networth/

Zakem, V., \& Saunders, P. J. (2016, March 17). How Russia views its 'compatriots' in the near abroad. The National Interest. Retrieved August 8, 2017, from http://nationalinterest.org/feature/how-russia-views-its-compatriots-the-near-abroad-15516

Zakrytie fabriki Roshen v Lipetske okazalos' konservatsiē. (2017, May 14). Retrieved August 4, 2017, from http://lenta.ru/news/2017/05/14/roshen/

Zashkil'niak, L. (2016). Radians'ki mify v suchasniī ukraïns'kiī istoriohrafiï: Chas zmin i zamin. Istoriia ta istoriohrafiia $v$ IEvropi, 2016(5). Retrieved June 15, 2017, from_http:// clio.Inu.edu.ua/wp-content/uploads/2014/12/\%.pdf

Zhit' v 'Russkol Evrope' predlagaet zastrol shchik ZhK 'TSvetnol bul'var' v Kaliningrade. (2017, April 6). Retrieved August 4, 2017, from www.newsvl.ru/vlad/2017/04/06/158085/

Zima, E. (2018, April 19). Russkaia Evropa—russkim Latvii. Retrieved June 27, 2018, from http://vesti.lv/statja/segodnja/2018/04/19/russkaya-evropa-russkim-latvii

Zürcher, C. (2007). The post-Soviet wars: Rebellion, ethnic conflict, and nationhood in the Caucasus. New York, NY: New York University Press. 